\title{
Peningkatan Pengetahuan Penyalahgunaan Napza Di Masa Pandemi Covid-19
}

\author{
Ika Setyawati ${ }^{1}$ \\ Departemen Biokimia, Progam Studi Pendidikan Dokter, Universitas Muhammadiyah Yogyakarta, Jalan Brawijaya, Kasihan, Bantul, \\ Yogyakarta, 55183, Telepon (0274) 387656 \\ Email: ikasetyawati.dr@umy.ac.id \\ DOI: $10.18196 / \mathrm{ppm} \cdot 39.106$
}

\begin{abstract}
Abstrak
Kondisi wabah pandemi Coronaviruses Disease 2019 (Covid-19) tak kunjung berakhir. Hal ini memberi dampak buruk terhadap berbagai aspek kehidupan baik kesehatan, pendidikan, sosial, ekonomi, budaya, psikis, mental, dan lainnya. Salah satu dampak buruk dari aspek sosial, psikis, dan mental adalah adanya kasus penyalahgunaan narkoba yang masih kita jumpai pada masa pandemi ini, bahkan kasusnya mengalami peningkatan. Kegiatan penyuluhan ini bertujuan memberikan pengetahuan dan kewaspadaan masyarakat terhadap penyalahgunaan NAPZA sehingga bisa dilakukan tindakan pencegahan. Pelaksanaan kegiatan secara virtual melalui aplikasi Google Meet kepada pemuda dusun Brajan, Pleret, Bantul, Yogyakarta. Sebelas peserta kegiatan mendapatkan pendidikan kesehatan berupa pemaparan materi dan diakhiri dengan sesi tanya jawab. Peningkatan pengetahuan diukur dengan cara membandingkan perbedaan antara nilai pretest dan nilai posttest sehingga diketahui peningkatan nilai posttest dibandingkan nilai pretest. Hasil kegiatan berupa peningkatan pengetahuan penyalahgunaan NAPZA pada seluruh peserta (100\%). Kegiatan ini telah memberikan manfaat bagi pemuda dan masyarakat serta peningkatan pengetahuan tentang penyalahgunaan NAPZA.
\end{abstract}

Kata Kunci: pengetahuan, NAPZA, Covid-19

\section{Pendahuluan}

Narkotika, Psikotropika, dan Zat Adiktif lainnya (NAPZA) sudah tidak asing bagi masyarakat. Pemanfaatan NAPZA dalam bidang kesehatan dan kedokteran sangat membantu dalam penanganan kasus penyakit tertentu sesuai indikasi. Namun, banyak juga kasus penyalahgunaan NAPZA yang terjadi di masyarakat. Berdasarkan data dari Badan Narkotika Nasional (BNN) bahwa peningkatan kejadian penyalahgunaan NAPZA mengalami peningkatan sebesar 0,03\% dari tahun 2017 hingga 2019 (Meiliana, 2019).

Peningkatan kasus penyalahgunaan NAPZA masa pandemi Covid-19 diungkapkan oleh Kapolda Metro Jaya, Irjen Pol Nana Sudjana, bahwa Jumlah kasus meningkat $120 \%$ di bulan April dibandingkan bulan Maret 2020 (Marhaenjati, 2020). Situasi pandemik Covid-19 dapat memicu munculnya stres sehingga dapat memengaruhi seseorang agar terjerumus dalam pemakaian NAPZA (Kholik et al., 2014). Pandemi ini dapat menyebabkan terjadinya kesulitan ekonomi, kehilangan pekerjaan, peningkatan jumlah pengangguran, peningkatan jumlah pekerja ter-PHK, bekerja dari rumah, pembelajaran jarak jauh, pembatasan sosial berskala besar (PSBB), dan meningkatkan rasa kekhawatiran serta panik yang berlebih karena takut terjangkit Covid-19 yang selanjutnya dapat menjadi salah satu faktor pendorong seseorang menjadi stres (Natalia dan Humaedi, 2020).

Berdasarkan hasil Focus Group Disccussion (FGD) dengan kepala dukuh dan pemuda Brajan, tingkat pengetahuan tentang NAPZA masih rendah dan adanya rasa kekhawatiran takut terjerumus dalam penyalahgunaan NAPZA tersebut. Berdasarkan uraian tersebut, tujuan kegiatan pengabdian masyarakat ini adalah memberikan pengetahuan dan kewaspadaan masyarakat terhadap penyalahgunaan NAPZA sehingga masyarakat dapat mencegahnya.

\section{Metode Pelaksanaan}

Teknis pelaksanaan kegiatan pengabdian masyarakat sebagai berikut.

1. Mengadakan pertemuan dengan kepala dukuh dan perwakilan pemuda masyarakat setempat 
untuk identifikasi masalah kesehatan utama dilingkup pemuda dengan cara FGD.

2. Penjelasan/panduan pengguanan aplikasi Google Meet dan uji coba penggunaannya telah diinformasikan kepada pemuda sebelum kegiatan melalui aplikasi Whattsapp Messanger.

3. Kegiatan dilaksanakan secara virtual dengan aplikasi Google Meet.

4. Pelaksanaan kegiatan dimulai dengan melakukan pretest sebanyak 10 soal dalam bentuk pilihan ganda sebelum kegiatan edukasi kesehatan. Kegiatan pretest dilaksanakan selama 10 menit.

5. Kegiatan edukasi kesehatan dilaksanakan dengan memberikan penjelasan sesuai urutan slide power point materi.

6. Setelah sesi eduksi kesehatan selesai, melakukan posttest sebanyak 10 soal dalam bentuk pilihan ganda (soal posttest sama dengan soal pretest). Kegiatan posttest dilaksanakan selama 10 menit.

Responden kegiatan dipilih secara acak dari populasi pemuda masyarakat. Responden adalah pemuda dewasa berusia lebih dari 18 tahun dan bersedia mengikuti kegiatan pengabdian masyarakat dengan pernyataan lisan dan telah mendaftar kepada penyelenggara kegiatan. Data dianalisis secara deskriptif dengan menghitung rerata nilai pretest dan posttest.

\section{Hasil dan Pembahasan}

Upaya yang telah dilakukan masyarakat untuk mencegah penularan Covid-19 sesuai himbauan pemerintah adalah gunakan masker, cuci tangan dengan sabun/memakai hand sanitizer, batasi keluar rumah untuk hal yang tidak perlu, tidak melakukan pertemuan tatap muka dalam skala besar, menghindari kerumunan, dan physical distancing (BNPB dan UI, 2020). Salah satu cara untuk mematuhi himbauan pemerintah tersebut adalah dengan melaksanakan kegiatan pengabdian kepada masyarakat secara virtual. Kegiatan ini dihadiri oleh 11 pemuda masyarakat Brajan, Pleret, Yogyakarta. Hasil kegiatan berupa rerata nilai pretest dan posttest seluruh peserta dapat dilihat pada Tabel 1.

\begin{tabular}{cc} 
Tabel 1. Perbandiangan Rerata Nilai Pretest dan Posttest Pengabdian Masyarakat \\
\hline Kegiatan & Rerata Nilai \\
\hline Pretest & 51,81 \\
\hline Pretest & 79,09 \\
\hline
\end{tabular}

Peserta dengan nilai pretest $\leq 50$ sebanyak 7 orang $(63,63 \%)$ dari total peserta sehingga masih perlu dilakukan edukasi kesehatan untuk meningkatkan pengetahuan. Kegiatan edukasi dilakukan oleh narasumber dokter umum dengan menampilkan materi power point disertai penjelasan. Materi edukasi meliputi definisi, penggolongan, kegunaan, efek samping/dampak, faktor penyalahgunaan, upaya pencegahan penyalahgunaan, dan aspek Islam terhadap penggunaan NAPZA. Sesi diskusi tanya jawab dilaksanakan setelah pemaparan materi. 


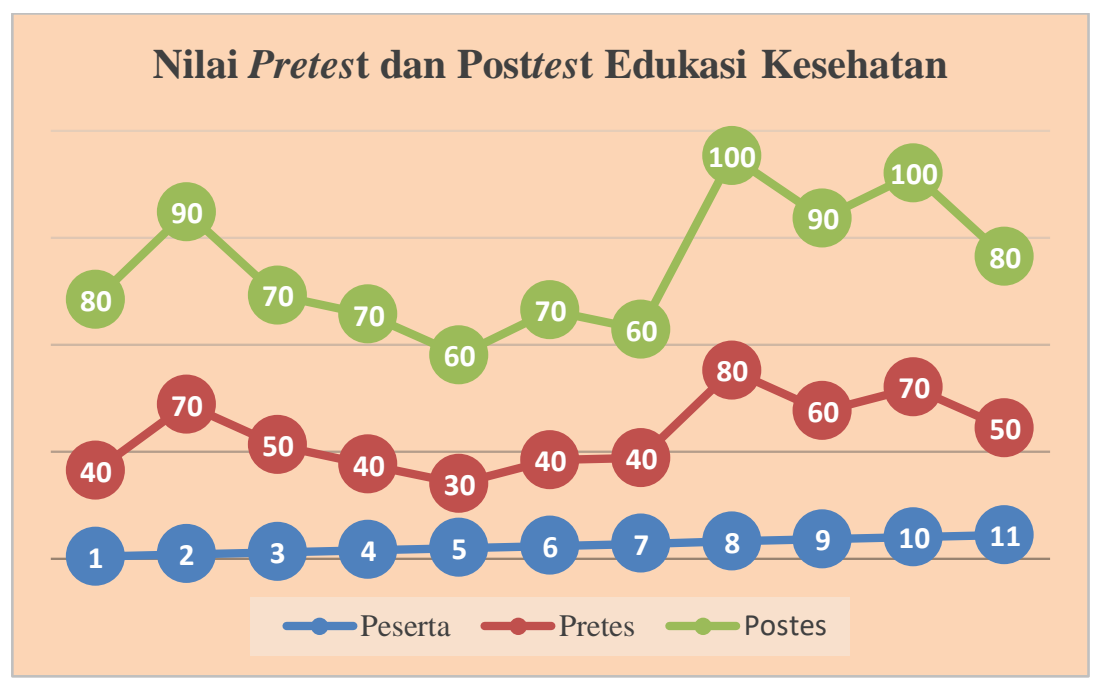

Gambar 1. Grafik Nilai Pretest dan Posttest Seluruh Peserta Pengabdian Masyarakat

Seluruh peserta mendapatkan nilai posttest lebih dari 50 dan mengalami peningkatan nilai dibandingkan nilai pretest (Gambar 1.) dan rerata nilai posttest lebih tinggi dari pretest (Tabel 1). Hasil tersebut menunjukkan bahwa seluruh peserta lebih dapat mengetahui, memahami, dan mampu menyerap informasi pengetahuan dari proses edukasi yang telah disampaikan oleh narasumber meskipun dilaksanakan secara virtual.

Edukasi kesehatan dengan cara penjelasan materi secara langsung/ceramah merupakan salah satu cara edukasi yang efektif dilakukan. Hasil penelitian di Kabupten Bima tentang edukasi kesehatan terhadap kemampuan ibu dalam deteksi dini ISPA pada balita adalah pengetahuan ibu meningkat setelah diberikan pendidikan kesehatan (Baiq dan Murniati, 2016). Intervensi ceramah efektif untuk meningkatkan pengetahuan ibu hamil terhadap deteksi dini kehamilan risiko tinggi yang bermakna pada masing-masing kelompok kontrol dan kelompok perlakuan (Salsabila et al., 2018).

Perlu dilakukan upaya pencegahan penyalahgunaan NAPZA yang makin meningkat meskipun dalam kondisi pandemi. Selain edukasi kesehatan seperti yang telah dilakukan pada kegiatan pengabdian masyarakat ini, dapat dilakukan beberapa metode pendekatan yang dapat dijadikan pilihan pemecahan masalah dalam pencegahan dan penanggulangan penyalahgunaan NAPZA pada masa pandemi Covid-19, yaitu menurut BNN, 2020b sebagai berikut.

(1) Pendekatan Agama

Peningkatan kepribadian yang menaati peraturan setiap agamanya untuk menjauhi pengaruh NAPZA penting agar seseorang tidak mudah tergoda iming-iming kesenangan duniawi.

(2) Pendekatan Psikologi

Langkah persuasif ini dapat dilakukan untuk menanamkan kesadaran dari dalam hati mereka melalui orang-orang terdekat dan memberikan nasihat dari hati ke hati sesuai dengan karakter kepribadiannya masing-masing. Bagi orang yang telah telanjur terjurumus dalam penyalahgunaan NAPZA, pendekatan ini dapat melihat latar belakang seseorang, yaitu tipe ekstrovert (terbuka), introvert (tertutup), atau sensitif. Orang terdekat dapat memotivasi orang yang sudah terjerumus untuk melakukan pemulihan secara mandiri atau mengikuti program rehabilitasi.

(3) Pendekatan Sosial

Menanamkan kepada diri mereka bahwa kehadiran diri mereka sangatlah penting di tengah teman, keluarga, dan masyarakat sehingga dapat membentuk assertiveness dan self regulation dalam dirinya. Pendekatan ini juga memerlukan bantuan masyarakat untuk dapat merangkul dan menerima kehadirannya di komunitas sosialnya. 


\section{Simpulan}

Simpulan kegiatan pengabdian kepada masyarakat ini adalah terdapat peningkatan pengetahuan penyalahgunaan NAPZA di masa pandemi Covid-19.

\section{Ucapan Terima Kasih}

Ucapan terima kasih kami sampaikan kepada Kepala Dukuh Brajan yang telah memberikan kesempatan dan ijin pelaksanaan kegiatan. Selain itu, ucapan terima kasih kami sampaikan kepada pemuda Brajan yang telah bersedia mengikuti kegiatan, Tim KKN Tematik Kesehatan 2020 Kelompok 11, dan LP3M yang telah memberikan support dana pengabdian masyarakat.

\section{Daftar Pustaka}

BNN. (2019). Pengertian Narkoba Dan Bahaya Narkoba Bagi Kesehatan.

BNN. (2020b). Ramadhan: Ancaman Narkoba Di Tengah Pandemi Corona. Bnn.Go.Id. https://bnn.go.id/ramadhan- ancaman-narkoba-tengah-pandemi- corona/.

BNPB dan UI. (2020). Pengalaman Indonesia dalam Menanggulangi Wabah Covid-19 Periode Januari-Juli 2020. Jakarta: BNPB \& UI.

Kholik, S., Mariana, E.R., \& Zainab. (2014). Faktor-Faktor yang Memengaruhi Penyalahgunaan Narkoba pada Klien Rehabilitasi Narkoba di Poli Napza RSJ Sambang Lihum. Kesehatan. https://doi.org/https://doi.org/10.31964/jsk.v5i1.13.

Marhaenjati, B. (2020). Kasus Narkoba Naik, Bandar Memanfaatkan Wabah Covid-19. BeritaSatu.Com. https://www.beritasatu.com/nasional/627 561-kasus-narkoba-naikbandar- memanfaatkan-wabah-covid19.

Meiliana, D. (2019). BNN: Penyalah Guna Narkoba di Indonesia Naik 0,3 Persen. Kompas.Com. https://nasional.kompas.com/read/2019/12/06/06052331/bnn-penyalahguna-narkoba-di-indonesia-naik-003-persen.

Sheilla, N. \& Humaedi, S. (2020). Bahaya Peredaran Napza pada Masa Pandemik Covid-19 di Indonesia. Prosiding Penelitian dan Pengabdian Masyarakat. Vol.7 No.2, Hal: 387-392. http://journal.unpad.ac.id/prosiding/article/view/28868/pdf.

Q. Salsabila, A. Utami, \& A. Nugraheni. (2018). "Efektivitas Edukasi Kesehatan (Ceramah dan SMS Gateway) terhadap Pengetahuan Deteksi Dini Kehamilan Risiko Tinggi pada Ibu Hamil," Diponegoro Medical Journal (Jurnal Kedokteran Diponegoro), Vol. 7, No. 2, Pp. 599-614, May. 2018. [Online]. 